\title{
3D investigation of steel fiber distribution in reinforced concrete by $\mathrm{X}$-ray microtomography
}

\section{Investigação 3D da distribuição de fibras de aço em concreto reforçado por microtomografia de raios $X$}

\author{
A.C. MACHADO \\ alecastro@lin.ufr.j.br \\ M. A. SILVA a \\ marcofcr@gmail.com \\ R. D. T. FILHO a \\ toledo@coc.ufrj.br \\ M. S. PFEIL a \\ mpfeil@coc.ufrj.br \\ I. LIMA a \\ inayacorrea@gmail.com \\ R.T. LOPES a \\ ricardo@lin.ufrj.br
}

\begin{abstract}
The effects of the inclusion of steel fibers in concrete have been widely studied in order to investigate possible changes in mechanical properties, such as the increase in tensile strength, ductility, stiffness, toughness (energy absorption capacity), and durability. An immediate consequence of this addition is the mitigation of concrete's brittle behavior, so that the material meets new quality requirements. In this context, it is important to study the spatial distribution of the entire internal structure of these materials. Three-dimensional computed microtomography is a non-destructive inspection technique used to characterize the internal structures of various materials based on X-ray interaction with the inspected object. Topological and morphological properties can be obtained directly in three dimensions by means of mathematical reconstruction of the radiographs, which allows analyzing, for example, porosity and distribution of objects. In this context, the aim of this study is to investigate the spatial distribution of steel fibers, as well as of porosity in reinforced concrete samples. To this end, we used a microtomography system calibrated to operate at a voltage of $80 \mathrm{kV}$, electric current of $100 \mu \mathrm{A}$ and a pixel size equal to $24 \mu \mathrm{m}$. The results showed low porosity and that the steel fibers were not uniformly distributed throughout the sample.
\end{abstract}

Keywords: X-ray, steel fibers, microtomography, porosity, concrete.

\section{Resumo}

Os efeitos da inserção de fibras de aço em concretos têm sido amplamente estudados com o objetivo de investigar possíveis modificações nas propriedades mecânicas, tais como, o aumento da resistência à tração, ductilidade, rigidez, tenacidade (capacidade de absorção de energia), e durabilidade. Uma das consequências imediatas dessa adição é a mitigação do comportamento frágil do concreto, de forma que o material passe a ter novas exigências de qualidade. Nesse contexto, é de grande importância o conhecimento espacial da distribuição de toda estrutura interna desses materiais. A microtomografia computadorizada tridimensional é uma técnica utilizada na caracterização de estruturas internas de diversos materiais, baseada na interação dos raios X com o objeto inspecionado, sendo considerado um ensaio não destrutivo. Propriedades morfológicas e topológicas podem ser obtidas diretamente em três dimensões através da reconstrução matemática das radiografias, o que possibilita analisar, por exemplo, a porosidade e a distribuição de diversos objetos. Nesse contexto, o objetivo desse trabalho é a investigação da distribuição espacial das fibras de aço, assim como da porosidade em amostras de concreto. Para tal, foi utilizado um sistema de microtomografia calibrado para operar com uma tensão de $80 \mathrm{KV}$, corrente elétrica de $100 \mu \mathrm{A}$ e um tamanho de pixel igual a $24 \mu \mathrm{m}$. Os resultados mostraram uma porosidade baixa e que as fibras de aço não estão distribuídas uniformemente ao longo da amostra.

Palavras-chave: raios $\mathrm{X}$, fibras de aço, microtomografia, porosidade, concreto 


\section{Introduction}

Non-reinforced, simple concrete is a fragile material, brittle, with low strength and tensile elongation capacity, thus, the inclusion of steel fibers in its composition has been widely employed in the construction industry. This fact is widely observed in several applications such as tunnel coatings, plant floors and concrete pipes, because tensile strength, ductility, toughness and durability are significantly improved with fiber addition [1].

The function of discontinuous steel fibers, randomly distributed is bridging the cracks that are formed in the concrete under external loads or when temperature or humidity changes occur in the environment. [2;3]. Steel fibers, when added to the concrete, hinder crack propagation due to their high elastic modulus. Because of the load-bearing capacity that the composite presents after cracking, the fibers allow stress redistribution in the material even when used in low amounts [4], so as to cause certain ductility after cracking. In this manner, if the fibers are resistant enough, well adhered to the cementitious matrix and in adequate amount, they help to maintain small crack openings, allowing the concrete to resist high tensile stresses, with a large strain capacity in the post-cracking stage $[2 ; 3]$. It should be highlighted that the level of stress that the fiber transfers through the cracks depends on several factors such as fiber length, amount (volume) and random distribution [4] One of the issues involved in the durability of steel fiber reinforced concrete, is that frequently the fibers do not receive corrosion pre-

\section{Figure 1 - Sample photography}

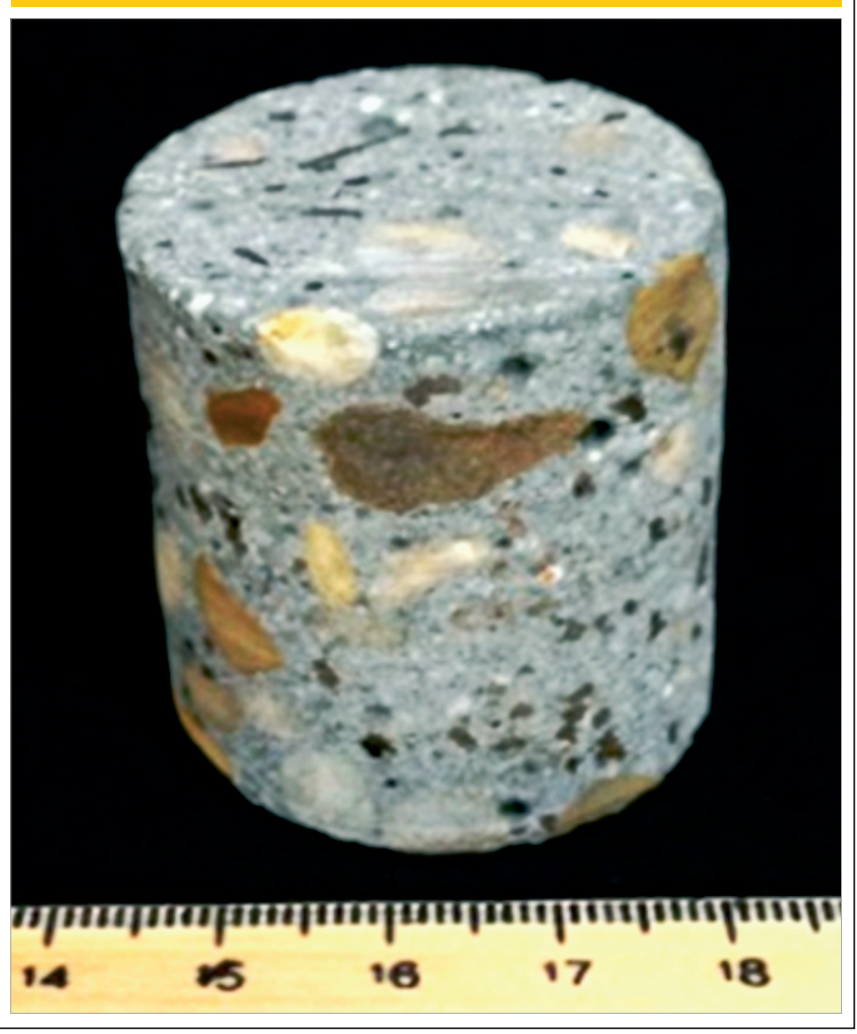

ventive treatment. This fact turns concrete durability conditioned to its confinement and, due to the restriction of crack propagation provided by the fibers, the resistance to the entry of aggressive agents increases with consequent increase of structure durability [4]. Concrete durability may be defined as the ability of concrete to resist weathering action, chemical attack, abrasion or any process of deterioration [5]. This definition is directly related to concrete permeability, which in turn may be described as the ease of a fluid to flow through a material under a given pressure gradient. Thus, permeability is not merely a characteristic of the material, but it also refers to a driving force acting on the fluid [6]. Therefore, we can say that a concrete with low permeability tends to prevent the entrance of aggressive agents into the matrix [7]. Another important parameter to assess concrete durability is porosity, which, besides having great influence on concrete mechanical strength (the higher the porosity, the lower the strength) directly affects its durability. Total porosity may be defined as the volumetric ratio of void spaces in concrete [8]. In other words, the higher the permeability of concrete, the greater will be pore connectivity and therefore the material will be more susceptible to external actions directly increasing deterioration speed and consequently affecting concrete durability. Excellent quality concretes are those with porosity about $1 \%$ [9]. In addition to pore volume, pore shape and dimension also affect concrete resistance. In general, for the same value of total porosity, smaller size pores result inhigher strength of the hydrated cement paste [10].

Although steel fibers can actually improve concrete behavior, we must be realistic about what we can really expect from their performance, especially if the amount of fibers is small (less than $1 \%$ by volume), as usually occurs [2; 3].

In this context, quantifying the amount (volume) of steel fibers embedded in the concrete and analyzing its spatial distribution, becomes animportant tool for quality assessment of this material. To this end, it is necessary to investigate its microstructure and several cutting-edge techniques are being developed such as acoustic emission, infrared thermography and 3D X-ray computed microtomography (microCT) [11].

High resolution microCT is a valuable tool that enables the morphological and topological analysis of the internal structures of several types of materials such as fiber reinforced concrete.

MicroCT is a non-destructive test based on the physical principle of $\mathrm{X}$-ray exponential attenuation when they interact with the object under study. The technique informs the distribution of the different phases in the material of interest [12]. The intensity of the transmitted, collimated X-ray beam that interacts with the object is recorded by a detector matrix placed on the opposite site to the source [13]. One of the great advantages of this technique is that it informs the internal structure of the object without submitting it to any kind of preparation method such as impregnation, thinning or polishing allowing quantifying parameters such as volume, size, shape, distribution and connectivity [14].

The goal of this study is to characterize a sample of steel fiber reinforced concrete and quantify total porosity and steel fiber volume to assess thickness spatial distribution of both, pores and fibers. At the end, 3D models of the studied medium are presented.

\section{Materials andexperimental program}

The sample used in this study was a steel fiber reinforced concrete cylinder with $(38.3 \pm 0.25) \mathrm{mm}$ of height and $(37.5 \pm 0.25)$ $\mathrm{mm}$ of diameter, shown in figure [1]. Other characteristics of the 
Table 1 - Characterization of the concrete and materials used

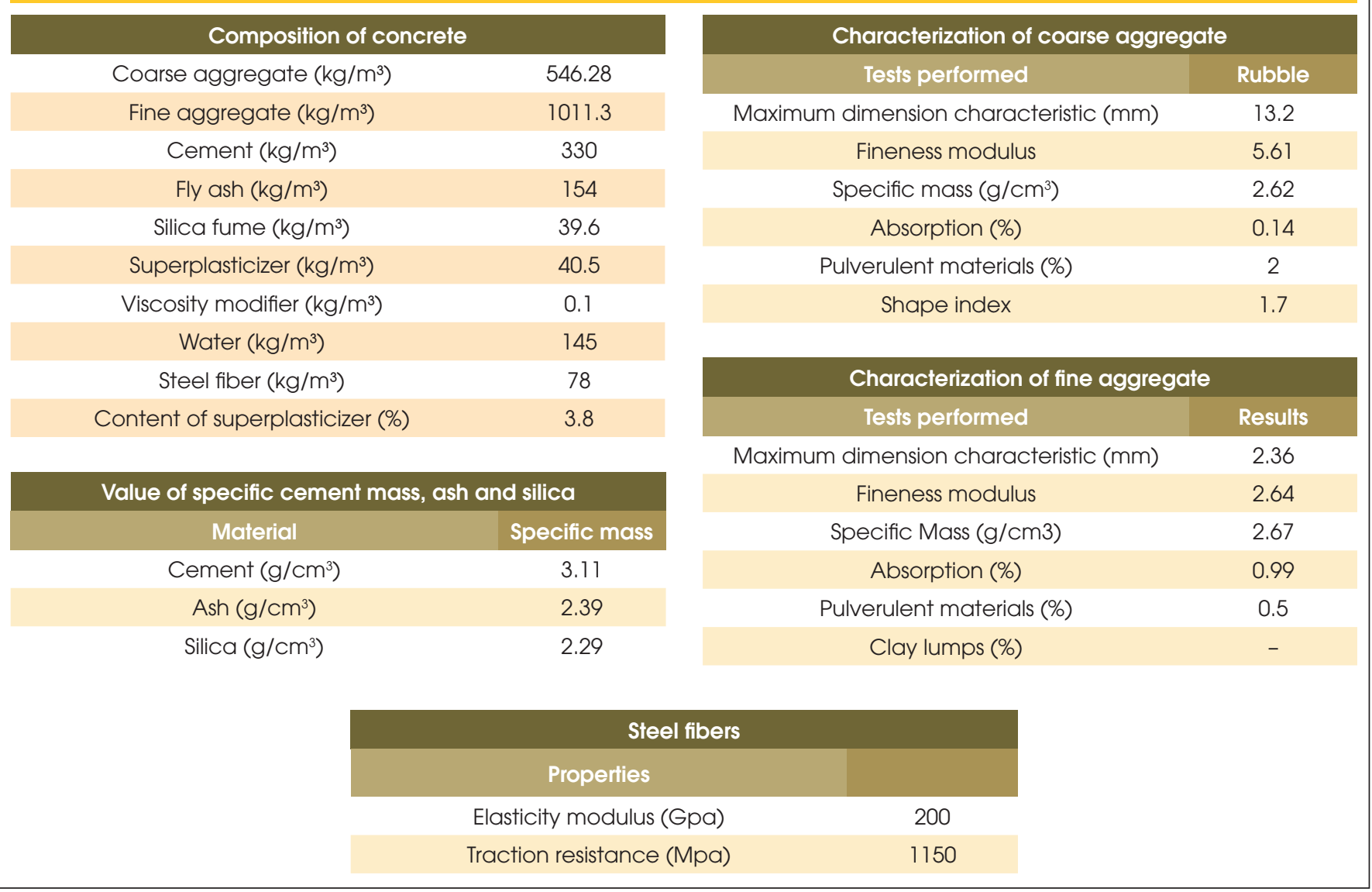

material under study such as concrete composition can be visualized in table [1].

It was prepared in a planetary, vertical-shaft concrete mixer (CIBI). Initially the equipment was moistened with water and the excess was removed with a cloth. Then, dry fine and coarse aggregates were thrown, and mixed for 1 minute for homogenization. Then, the cementitious materials were added and mixed for another minute. After this stage, $80 \%$ water was added, then the superplasticizer material and next the remaining water and mixed for 8 minutes to allow the complete action of the plasticizer. Finally, fibers were added and mixed for another 4 minutes. The entire mixing time was 14 minutes. After 48 hours, the test specimens were withdrawn from the molds and placed in a humid chamber with relative humidity higher than $95 \%$ and temperature of $(22 \pm 2){ }^{\circ} \mathrm{C}$. The aggregates used were round pebbles from the Amazon riverbed.

The microCT assay was conducted in a high energy system (Skyscan/Bruker, model 1173). The system was calibrated to work with a voltage of $80 \mathrm{kV}$ and current of $100 \mu \mathrm{A}$. The values of the electric current and acceleration voltage used in microCT tests depend on the combination of type of material and the experimental system used. Voltage value has to be such that the photons have energy enough to pass through the sample and transmit the necessary information for image formation at the receptor. This parameter directly influences image contrast. The higher the $\mathrm{kV}$, the higher the beam energy and its penetration in the material and the smallest the intensity difference among the photons from different densities of the inspected material (assuming a heterogeneous material), producing a smaller variation of radiation attenuation. Current value is attributed to the intensity of the X-ray beam, without changing the energy spectrum (the effective energy continues the same) and is related to the counting statistics of the electron beam in image construction. In this context, image quality optimization depends on the relation chosen between acceleration voltage and electronic current in the X-ray tube, and, of course, on other factors such as exposure time, mentioned throughout the text. The microCT system used had an internal aluminum filter with 1.0 $\pm 0.05 \mathrm{~mm}$ thickness at the exit of the X-ray tube. The filter reduces the contribution of low energy photons, minimizing beam hardening effect, which is an artifact of final image degradation in microCT tests. This type of artifact makes the edge appear brighter than the center, even when the material is homogenous.

Pixel size used was $24 \mu \mathrm{m}$, which is equivalent to a spatial resolution of $50 \mu \mathrm{m}$. This difference between spatial resolution and pixel size occurs because spatial resolution depends also on other factors, such as for instance, beam geometry and the unsharpness it forms

With that configuration, the distances source-sample and sampledetector were $177.4 \mathrm{~mm}$ and $186.6 \mathrm{~mm}$, respectively. Pixel size is related with sample size and microCT system size. Therefore, it is possible to obtain different magnification factors for different distance value combinations [15]. 
Figure 2 - Example of the images obtained at each stage of the process microtomography, (a) sample photography, (b) projection obtained in acquisition, (c) slice obtained in reconstruction (d) 2D visualization of the coronal, axial and sagittal sections and (e) 3D visualization

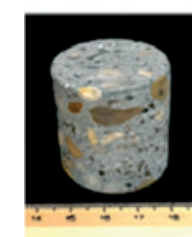

A Sample

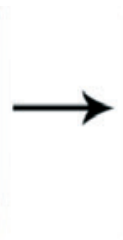

B

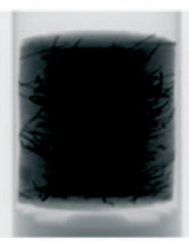

Projection

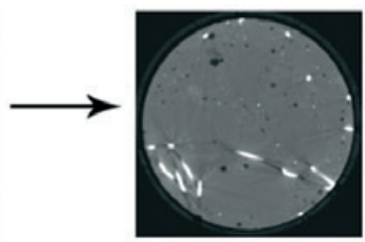

C Recontructed slice

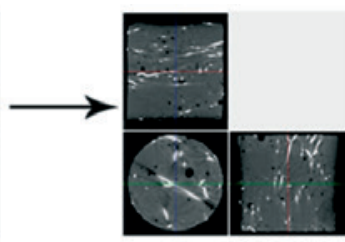

(D)

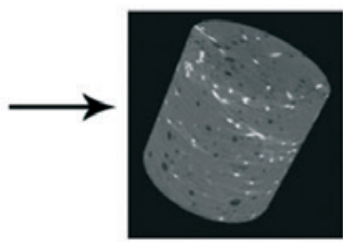

E 3D visualization
A flat-type detector, also known as flat panel detector, is a flat digital detector with isotropic pixel size of $50 \mu \mathrm{m}$, i.e., $50 \times 50 \mu \mathrm{m}$, operating with a maximum pixel matrix of $2240 \times 2240$. It was used to record the transmission of the X-ray cone beam. This detector has the advantage of producing distortion-free images.

Acquisition was performed from a concrete cylindrical sampleplaced on the system's handling table in such a way that its main $z$ axis was perpendicular to the radiation beam. In this manner, the sample was rotated $360^{\circ}$ along its $z$ axis, in $0.30^{\circ}$ steps. It is important to note that other image acquisition parameters can be adjusted; therefore an average of 05 frames was obtained over an exposure time of $800 \mathrm{~ms}$ for each radiography image.

After the acquisition process, the projections were reconstructed using the Nrecon ${ }^{\circledR}$ SkyScan - version 1.6.4.1 program [16] and InstaRecon - version 1.3.5.0 [17] whose algorithm is based on Feldkamp's studies [18]. The reconstruction program allows choosing several parameters to obtain a more accurate image quality. The parameters can be manually adjusted during reconstruction using the visualization function (previews). The fine tuning function of NRecon is designed to make the necessary adjustments according a series of previews. It is possible to adjust one parameter at a time, keeping all other parameters fixed, so that it is possible to select, one by one, the desired combination for a better image quality. From the options offered, we used the following:

i) Ring artifact: ring artifact appears as total or partial circles centered in the rotation axis which are caused by changes in the exit of the individual detectors or set of detectors. This reduction is applied to the projections before image pre-processing, so that the average projection is used for this purpose. The depth of this correction can be chosen in a 1 to 20 gap. In our study, we used a ring artifact reduction with a degree of 9 .

- ii) Beam hardening: besides the corrections that can be made during the test, another correction is possible by mathematical processing. This correction is made through linear transformation and its depth can be chosen according to the material density. A high order in the polynomial function can also be used for that purpose. Beam hardening correction can be made in different degrees (1\% to $100 \%$ ). A beam hardening artifact correction of $9 \%$ was applied in the present study.
- iii) Noise reduction: the kernel Gaussian smoothing filter is characterized as smoothing applied to projections. It smoothes each pixel within an $\mathrm{MxN}$ neighborhood, where $\mathrm{M}$ is the horizontal dimensionand $\mathrm{N}$ is the vertical dimension. It reduces noise and searches for a proper smoothing level using filters in different degrees (1 to 10). In this study, we used a Gaussian smoothing filter with degree equal to 8 .

In this stage, the results obtained are reconstructed slices. These slices provide both, 2D and 3D sample visualizations which can be digitally processed, therefore, qualitative and quantitative information may be obtained from these images after submission to a series of mathematical operations such as binarization, noise removal, image contrast improvement, etc. Figure [2] shows an example of images obtained in each stage of the microCT process. Once the acquisition and reconstruction stages are finished, it is necessary to analyze the images obtained. The SkyScan, CTAN ${ }^{\circledR}$ (v1.11.8.0) [19] program was used for image analysis and processing. In this stage, the goal was to quantify geometrical parameters related to concrete porosity and steel fibers. This quantification is performed only after image segmentation. Segmentation involves the selection of a threshold value to separate the porous space from other remaining phases in the material. In the present study, a simple global thresholding method was applied, with a single threshold value chosen to separate pores from the matrix. In a second stage, another threshold value was chosen to separate the fibers from the remaining materials [20]. In this manner, the

\section{Table 2 - $\mu$ CT-3D results}

\begin{tabular}{|ccccc|}
\hline Phase & $\begin{array}{c}\text { Volume } \\
\left(\mathrm{mm}^{3}\right)\end{array}$ & $\begin{array}{c}\text { Percentage } \\
(\%)\end{array}$ & $\begin{array}{c}\rho \\
(\mathrm{mm}-1)\end{array}$ & $\begin{array}{c}\Delta p \\
(\mathrm{~mm})\end{array}$ \\
\hline Pores & 604.69 & 1.58 & - & - \\
\hline Matrix & 37028.19 & 97.09 & - & - \\
\hline $\begin{array}{c}\text { Steel } \\
\text { fibers }\end{array}$ & 504.55 & 1.32 & 0.024 & 15.16 \\
\hline Total & 38137.43 & - & - & - \\
\hline
\end{tabular}




\section{Figure 3 - 3D models of the different phases of reinforced concrete: $(a)$ pores, (b) matrix + pores + steel fibers and (c) steel fibers}

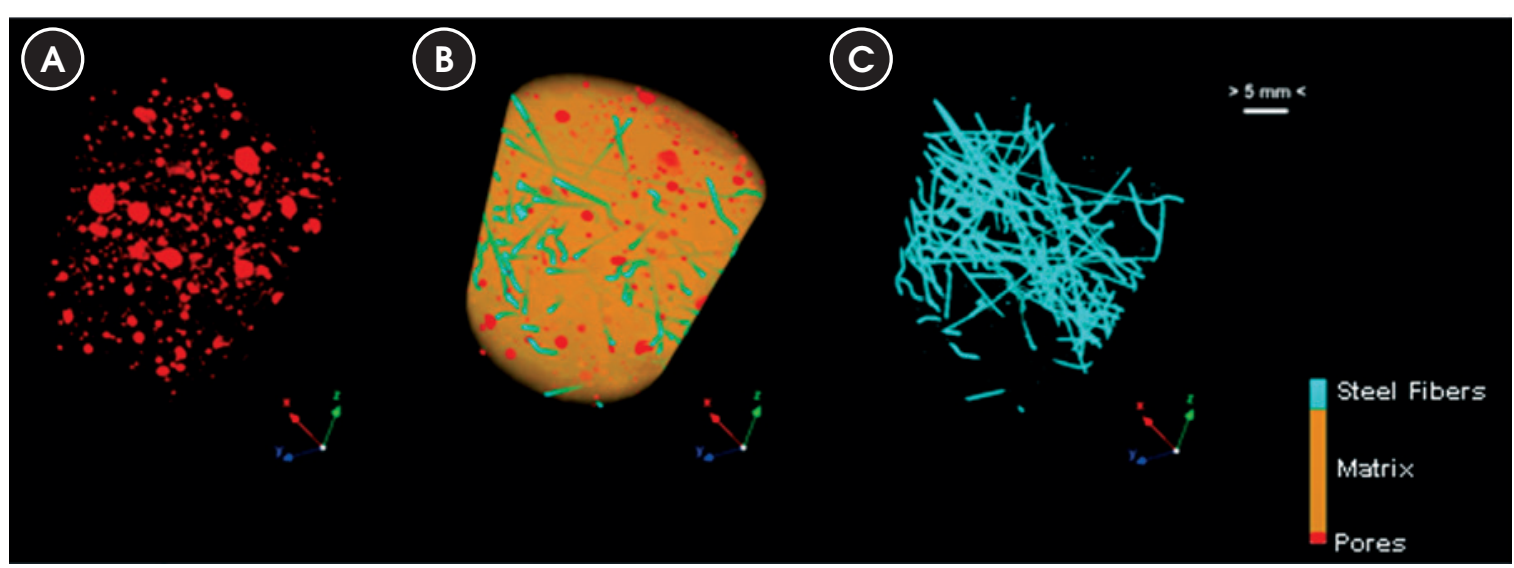

amount of black and white pixels/voxels belonging to the volume of interest ( $\mathrm{VOI}$ ), and consequently total concrete sample porosity, linear density of steel fibers $\left(\rho, \mathrm{mm}^{-1}\right)$, fiber separation $(\Delta, \mathrm{mm})$, i.e., spacing between them and thickness distribution of pores and steel fibers were determined. Pore, fiber and matrix volumes were essential in all the assessments.

\section{Results and discussion}

MicroCT results are shown in table [2]. They indicate that the steel fiber reinforced concrete sample studied has high quality, because according to [2;3], has steel fiber percent above the value recommended for high resistance concretes (1.32\%), ensuring enhancement of the performance of the mechanical properties. Another parameter that indicates the quality of the sample is total porosity, which was $1.5 \%$. This value may be considered low and directly influences the increase of concrete durability, because according to [9] excellent quality concretes are those with porosity about $1 \%$. Figure [3] illustrates 3D fiber distribution within the volume of interest studied, from the visualization of 3D models of sample phases. The figure shows that this distribution is not uniform, because it presents a random behavior, which may result in a decrease of fiber efficiency in repressing crack propagation in high resistance concretes. This non-uniform distribution suggests a problem of fiber-matrix adherence through anchoring effect.

However, total porosity is not the only parameter important for characterizing the pore space. Pore size distribution is also essential for understanding concrete durability. Figure [4] illustrates this result obtained through microCT, evaluated slice-by-slice. Ten pore size intervals are evidenced $(0.00-0.05 ; 0.05-0.10 ; 0.10-0.19$; $0.19-0.39 ; 0.39-0.77 ; 0.77-1.54 ; 1.54-3.08 ; 3.08-6.16 ; 6.16-12.33$; $12.33-24.65) \mathrm{mm}$. Most pores are not within the highest or lowest intervals, they concentrate within the $(0.19-0.39)$ and $(0.39-0.77)$ $\mathrm{mm}$ intervals. This distribution shows that more than $77 \%$ pores lie within the range from 0.10 to $1.54 \mathrm{~mm}$. The highest pore size range found ( 12.33 to $24.65 \mathrm{~mm}$ ) represents just $2.2 \%$ of total pores, and the lowest pore size range (between 0.00 and $0.05 \mathrm{~mm}$ ) only $8.53 \%$.
Other parameters that microCT enables to investigate are: fiber linear density $(\rho)$ and fiber separation $(\Delta \rho)$. The density $\rho$ is inversely proportional to the distance between the mean fiber axis, this implies in the number of paths through the solid structure by length unit. The value $\rho$ found in this study was $0.024 \mathrm{~mm}^{-1}$, this value was directly calculated in $3 D$. The separation $\Delta \rho$ is, essentially the thickness of the spaces defined by the binarized objects within the VOI, i.e., the average distance between the fibers. The value found for $\Delta \rho$ was $15.16 \mathrm{~mm}$. This value was calculated in $2 \mathrm{D}$ (slice-byslice). According to [21], low fiber density values and increasingly higher values of fiber separation are associated to small mechanical resistance of the sample under study.

The greatest benefit obtained in reinforcing a fragile matrix with fibers is to alter its behavior after cracking. The composite does not break after the beginning of matrix cracking, but it can suffer

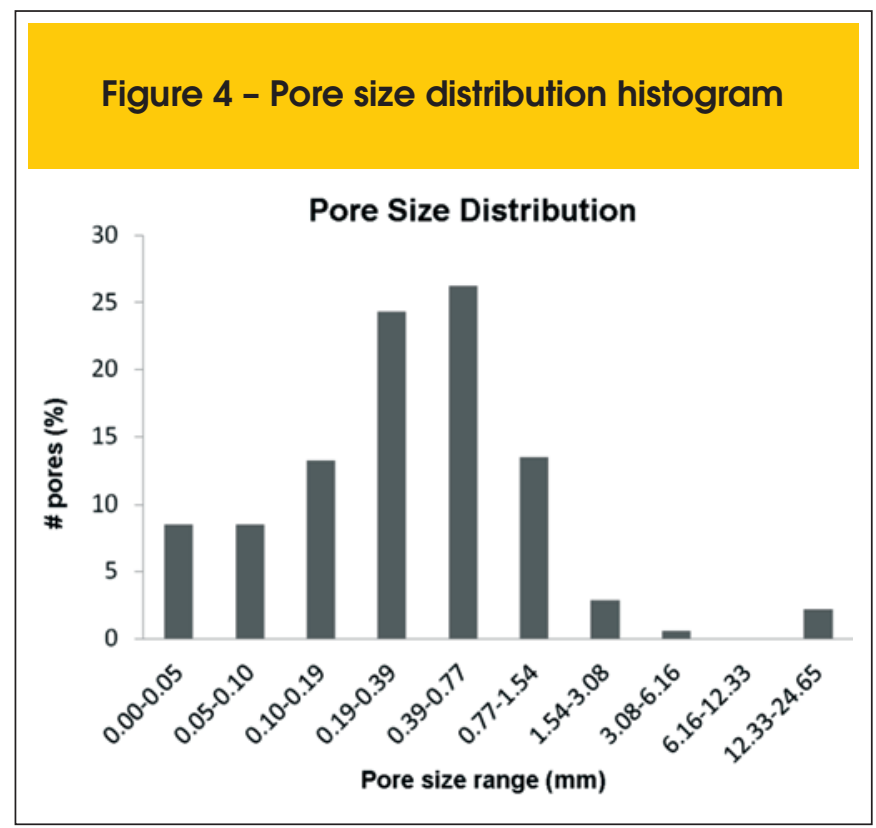




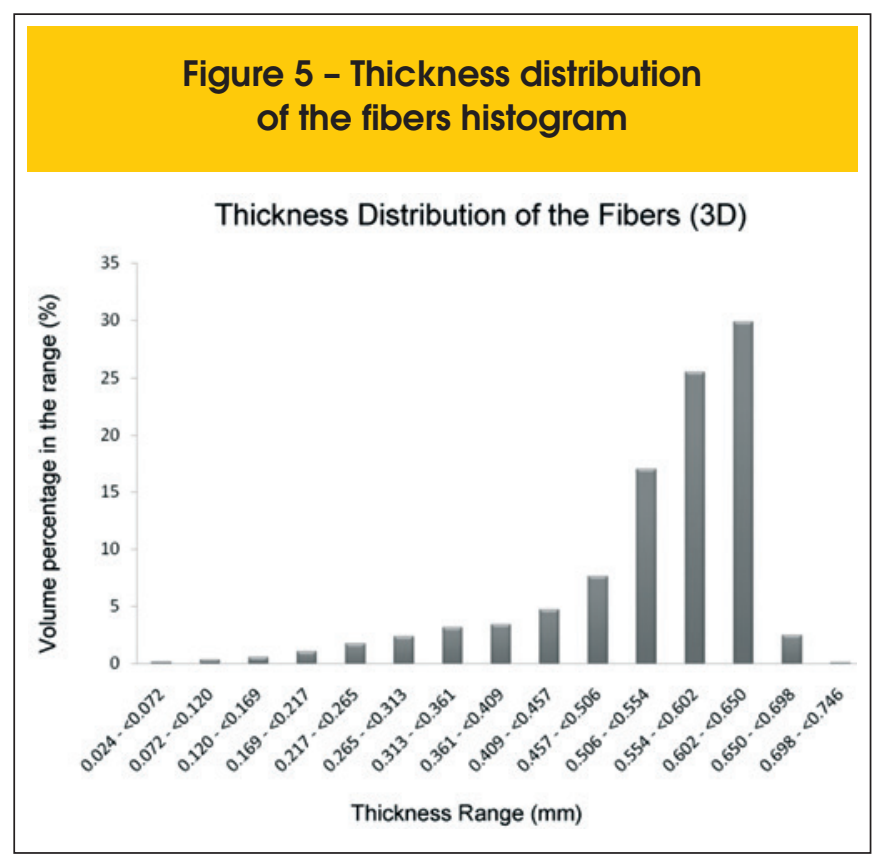

significant plastic deformation which makes it adequate for construction. To this end, fibers must be added in adequate volume, length and shape [5]. In this manner, fiber morphological characterization is essential in the evaluation of reinforced concrete quality. Fiber thickness distribution, figure [5], was directly analyzed in 3D. The method begins with a skeletonization, identifying the medial axis of all the structures.In this manner an adaptive sphere will help local thickness calculation for all the voxels along the identified medial axis. This adaptive sphere is a sphere inscribed in the binarized solid to maximize the tangency of its surfaces [22; 23] The result indicates steel fiber thickness uniformity, i.e., most fibers (more than $70 \%$ fiber volume) included in the sample lied in the thickness range between 0.50 and $0.65 \mathrm{~mm}$.

\section{Conclusions}

3D high resolution computed microtomography proved to be an adequate technique for steel fiber reinforced concrete characterization. Without any process of sample preparation, it was possible to qualitatively and quantitatively assess volume and thickness distribution of pores and steel fibers, besides the spatial distribution of the fibers in the sample.

Each stage of the microtomography process (acquisition, reconstruction and analysis) was carefully evaluated to obtain the best quality thus ensuring result reliability. The parameters used in each stage, such as voltage, current, physical and mathematical filters and segmentation thresholds were tested until an optimum final value was obtained.

The opportunity to assess steel fiber distribution and concrete porosity enables analyzing not only the final result of the sample, but also its entire production process.

\section{Acknowledgement}

To CNPq, CAPES e FAPERJ, for their financial support and scholarships granted for this study

\section{References}

[1] HAKTANIR, T., et al..Effects of steel fibers and mineral filler on the water-tightness of concrete pipes. Cement \& Concrete Composites, vol. 28, 2006; p. 811-816.

[2] MINDESS, S. Fibre Reinforced Concrete - Myth and Reality. Advances in Cement and Concrete, Book Conference Proceedings, Durham, New Hampshire, 1994, p. 217-222.

[3] MINDESS, S., YONG J. F., DARWIN, D. Concrete. New Jersey: Prentice Hall, 2 ed., 2002,cap 22.

[4] FIGUEIREDO, A. D.. Concreto com fibras de aço, São Paulo, 2000, Boletim Técnico - Escola Politécnica, Universidade de São Paulo.

[5] MIGLIORINI, A.V., GUIMARÃES, A.T.C., OZÓRIO, B.P.M., Fibras de aço em blocos de concreto: estudo para utilização em ambiente marítimo, Revista Matéria, v. 17, 2012, p. 997-1008.

[6] REINHARDT, H.W., Penetration and Permeability of Concrete: Barriers to organic and contaminating liquids., Rilem Report 16, E \& FN Spon, London, 1997.

[7] MIGLIORINI, A. V. Estudo de fibras de aço em blocos de concreto para a possível utilização em carapaça de molhes, Rio Grande, 2011, Dissertação (mestrado) - Universidade Federal do Rio Grande.

[8] NEVILLE, A. M., Properties of concrete, Longman, London, 4th ed., 1995.

[9] PESSÔA, J. R. C. Microtomografia com raios x e processamento de imagem na obtenção da porosidade do concreto, Rio de Janeiro, 2011, Tese (doutorado) - Universidade do Estado do Rio de Janeiro.

[10] CARVALHO, G., et al. Caracterização do concreto utilizando microtomografia por raios $\mathrm{x}$ e scanner comercial, CNMAC, Águas de Lindóia, SP, ISSN 1984-820X, v.3, p. 694-700, 2010.

[11] ROUGELOT, T., et al. About microcracking due to leaching in cementitious composites: X-ray microtomography description and numerical approach, Cement and Concrete Research, 40(2), 2010, p. 271-283.

[12] LANDIS, E. N., KEANE, D.T.. X-ray Microtomography, Materials Characterization, 61(12), 2010, p. 1305-1316.

[13] BRAZ, D., et al. Study of the concrete overlay (whitetopping) in paving using computed tomographic system, Nuclear Instruments and Methods in Physics Research Section A: Accelerators, Spectrometers, Detectors and Associated Equipment, 579(1), 2007, p. 510-513.

[14] MACHADO, A. C., et al. Effect of 3d computed microtomography resolution on reservoir rocks, Radiation Physics and Chemistry, vol. 95, 2014; pp. 405-407.

[15] LIMA, I., DE ASSIS, J.T., LOPES, R.T., Three-dimensional conic beam X-ray microtomography in bone quality, SpectrochimicaActa Part B, 64, p. 1173-1179, 2009.

[16] NRECON, SkyScan/Bruker micro-CT, Kartuizerweg 3B 2550 Kontich, Belgium, 2011.

[17] INSTARECON $®$, CBR Premium 12-8K $\mathrm{K}^{\mathrm{TM}}$, InstaRecon, Champaign, IL, USA, 2011.

[18] FELDKAMP, L.A.,L. C. Davis, and J. W. Kress, Practical cone beam algorithm, J Opt Soc Am A, vol. 1,1984, p. 612-619.

[19] CTANALYSER. The user's guide, Skyscan/Bruker micro-CT, Kartuizerweg 3B 2550 Kontich, Belgium, 2012. 
[20] PROVISA, J. L., et al. X-ray microtomography shows pore structure and tortuosity in alkali-activated binders, Cement and Concrete Research, 42(6), 2012, p. 855-864.

[21] DAMILAKIS, J., et al. An update on the assessment of osteoporosis using radiological techniques, Eur. Radiol. Jun; 17, 2007, p. 1591-602.

[22] CTANALYSER. Morphometric parameters measured, Skyscan/Bruker micro-CT, Kartuizerweg 3B 2550 Kontich, Belgium, 2012.

[23] REMY, E., THIEL, E., Medial axis for chamfer distances: computing look-uptables and neighbourhoods in 2D or 3D, Pattern Recognition Letters, v. 23, 2002, p. 649-661. 